\title{
Erratum to: Corporate Reputation Measurement: Alternative Factor Structures, Nomological Validity, and Organizational Outcomes
}

\author{
James Agarwal · Oleksiy Osiyevskyy • \\ Percy Samoel Marquina
}

Published online: 26 August 2014

(C) Springer Science+Business Media Dordrecht 2014

\section{Erratum to: J Bus Ethics}

DOI 10.1007/s10551-014-2232-6

The name of the third author has erroneously registered as Percy M. Feldman. It should read Percy Samoel Marquina instead.

The online version of the original article can be found under doi:10.1007/s10551-014-2232-6.

J. Agarwal · O. Osiyevskyy ( $₫)$

Haskayne School of Business, University of Calgary,

2500 University Dr NW, Calgary, AB T2N 1N4, Canada

e-mail: oleksiy.osiyevskyy@haskayne.ucalgary.ca

J. Agarwal

e-mail: james.agarwal@haskayne.ucalgary.ca

O. Osiyevskyy

D'Amore-McKim School of Business, Northeastern University,

360 Huntington Ave, Boston, MA 02115, USA

P. S. Marquina

CENTRUM, Pontificia Universidad Católica de Peru (PUCP),

Lima, Peru

e-mail: percy.marquina@pucp.pe 